\title{
THE SYSTEM OF COOPERATION OF ACTORS IN OPEN AND DISTANCE LEARNING
}

\author{
Pierre Benjamin Rakotomahenina ${ }^{1}$, Olivier Origène Andriamasimanana ${ }^{* 2}{ }^{*}$ \\ $1,{ }^{* 2}$ Management Department - Faculty of Economics, Management and Sociology- University of \\ Antananarivo, Madagascar
}

DOI: https://doi.org/10.29121/ijetmr.v7.i8.2020.742

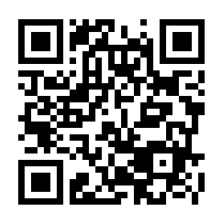

Article Citation: Pierre Benjamin Rakotomahenina, and Olivier Origène Andriamasimanana. (2020). THE SYSTEM OF COOPERATION OF ACTORS IN OPEN AND DISTANCE LEARNING. International Journal of Engineering Technologies and Management Research, 7(8), 12-20. https://doi.org/10.29121/ijetmr.v7 i8.2020.742

Published Date: 9 August 2020

Keywords:

Cooperation

Stakeholder Interaction

Open and/or Distance Learning

Management

Organization

\section{ABSTRACT}

The purpose of this article is to show the mechanism of cooperation at the level of teaching staff, students and administrative and technical staff as the three main actors in open and/or distance learning (ODL). The participatory observation approach carried out within the ODL organization in management sciences at the University of Antananarivo (Madagascar) has made it possible to bring out the result of the configuration of community - organic cooperation based on social identification and solidarity. The ODL platform constitutes a fundamental mechanism for ensuring the functioning of cooperation between stakeholders.

\section{INTRODUCTION}

Nowadays, open and/or distance learning (ODL) is an unavoidable orientation in the university world due to its international expansion (Batime C. \& Weber E., 2007). This training system allows a student to learn, alone or in collaboration, with different means of communication and distance support from people - resources (Gérin-Lajoie Serge, 2011). The definition given by AFNOR shows ODL as a training system designed to allow individuals to train without going to a training location and without the physical presence of a trainer.

Therefore, it is necessary to consider the ODL as a flexible training device in time and space. This idea of flexibility characterizes the considerable change in the ODL from traditional face-to-face training. That is to say, the transition from a state of knowledge transmitter (in traditional training) to that of facilitator of knowledge building in ODL requires a whole change in the professional identity of the trainer, because he is no longer the main agent who d i s p e n s e s knowledge but rather a catalyst. According to Denis B. (2003), the shift from face-to-face to distance training is upsetting all the roles of the actors.

In view of the distance in space between all the players in the ODL, the cooperation mechanisms play a primordial role for the proper functioning of the system in order to transform the input elements into output elements (according to the ISO standards version 2015). From this perspective, the group is considered as a center for analysis of cooperation because higher education students are frequently invited to work in groups to acquire knowledge (Laurent Cosnefroy and Sonia Lefeuvre, 2018). Theoretical developments in group movement show that

(C) 2020 The Author(s). This is an open access article distributed under the terms of the Creative Commons Attribution License, which permits unrestricted use, distribution, and reproduction in any medium, provided the original author and source are credited. 
the group with which it identifies is called the "ingroup", or home group, while groups in which it does not integrate constitute the "outgroup" (Elsbach, 1999). The question is: what is the mechanism of cooperation in the group? In order to find elements of answers, the construction of cooperation in a group will be shown on the basis of the analysis of two experiments.

The first concerns the research carried out by Moreno Jacob called "sociometry". This psycho-sociologist gave the name "sociometry" to a method capable of measuring relationships of sympathy and antipathy that may exist within a group. This technique consists of asking each member of the group to identify those they would choose as friends, neighbours or collaborators. Once the data are collected, a sociogram can be drawn up that summarizes the relationships within the group in a figure. This represents the rejections, divisions or conflicts that mark the internal dynamics of the group. Monie Roger (1986) associates himself with the research initiated by Moreno Jacob when he says that specific instruments had to be found for the study of groups that could illustrate their anatomy and psychology, sociometry came at the right time with its group instrument: the sociogram. The latter thus constitutes a graphic representation of the relations within a group established on the basis of the sociometry method, which is considered to be a technique for observing the cooperation of actors within a group. Consequently, the cooperation of group members is particularly highlighted in the analysis of "sociometry".

Lewin's experience with Training group (or T. group)" concerns the second application. The group is part of Lewin's field of research. He experimented with it in 1946, first by accident, then systematically, by centering small groups on themselves, giving no other object to their common work than the study of their own existence and evolution. The T. group, also known as a diagnostic group, is a group closed in on itself, isolated from the outside world, without a leader, an organization or a program, which has no other object than to exist, on an experimental basis, for a few days (Monie Roger, 1986). This technique ranges from individual utopia to collective organization. According to Marion Stéphane and Senicour Patrick (2003), the creation of an organization takes place along a continuum starting from the emergence of the idea, which is by nature immaterial, in the mind of the individual promoter or in a small team. The aim is to achieve, after certain periods of time, the social organization constituted by the cooperative relationship. Thus, Lewin's "T. group" shows that the constitution of cooperation is unpredictable, but experience has shown that it is full of energy.

Following the analysis of these experiences, the mechanism of interaction of the actors in the group at the ODL level plays a key role. This system of interactions appears to be the basis of the concept of cooperative learning. It is a pedagogical device that consists of having learners work in groups small enough that each one has the opportunity to participate in a collective task that has been clearly assigned. In addition, groups of students are expected to complete the task without the direct and immediate supervision of the teacher (Bourgeois, E. Nizet, J., 2005). Yet the interaction between actors in distance education may be limited in comparison to face-to-face teaching at the same time and in the same place. (Jacques Wallet, 2004). Faced with this limitation, how can cooperation between the actors of the ODL be ensured? The issue is not only theoretical, it is also methodological. While it is more usual to study communication practices within the relatively limited framework of a given system, such as a digital campus, a Moodle-type platform or a discussion forum, it is methodologically delicate to study interactions when the instruments are not known a priori. (Cédric Fluckiger, 2011).

There are several instruments for cooperation in the group. First of all, the ODL platform is the inevitable tool in distance learning. This software allows the administration of cooperative relations between technical, administrative and pedagogical actors. In addition, it provides a harmonized framework and a means of determining the traceability of the actors' activities through the management of registrations, production and dissemination of courses, tutorial support, pedagogical monitoring and evaluation. The main interest of a platform is to provide distance learning, asynchronously and with permanent access for several users.

Secondly, Serge Gérin-Lajoie, Claude Potvin, (2011) proposes teaching materials from a digital disc or a course website. They are offered slightly more varied learning activities. For example, it is possible to visit websites, do online exercises (quizzes) or simulations and participate in exchanges by e-mail or forum; these tools are also used for coaching. Although the majority of learning activities in such courses are asynchronous, cooperation is easier to organize.

It is indeed a question of giving the actors the opportunity to appropriate the digital worlds and to see how digital tools can enable them to appropriate the world. (Stines Marielle S., 2017). Digital technology is not only an educational object, it is also a tool that can be used in the service of education. Successful experiments combine at least three key elements in each case (Hélène Grimbelle and Antonin Cois, 2017). First of all, they really involve the 
cooperation of the actors in the educational team, if possible as soon as the desired material is defined (i.e. they propose a preliminary analysis where uses are anticipated). Then, they accompany and train these same teams in their use. Finally, they are monitored, evaluated, and focus on the conditions for the maintenance and renewal of the equipment. According to other authors (Martine Cauvin and Jacques Lacombe, 1999).The implementation of a socalled "virtual" approach requires a set of tools and services to be made available to the academic community. The main functions to be assumed concern the management of learning (organizing, negotiating pathways), content (creating, distributing, accessing resources) and cooperation between stakeholders, whether they belong to the teaching or learning community.

Furthermore, the tool via social networks is considered a digital space for cooperative learning, both formal and informal (Nahla Aljerbi, 2015). Students support the idea of using social networks in an institutional context as a tool for formal cooperation with their teachers, especially when the number of students is high and student-teacher interaction is so necessary. Social networks are often used as a means of cooperation to foster student-student and student-teacher interactions (Bowman, N. D. \& Akcaoglu, M, 2014).

Indeed, there are many instruments to ensure interaction between the ODL actors. However, it is necessary to go further in the search for configurations of cooperation between the actors, more particularly at the level of the ODL.

\section{MATERIALS AND METHODS}

To know the reality on the ground, an organization already operational since the 2015 academic year, within the Faculty of Economics, Management and Sociology of the University of Antananarivo (Madagascar) was chosen as the empirical study area. This is the Open and Distance Learning in Management Sciences, called Management ODL. It is part of the national plan for the development of higher education in Madagascar, of which the promotion of the digital university is one of the strategic orientations designed by the State. This pilot project in the field of Social Sciences enables graduates of the public university to be competitive, creative and employable in the country's economy. It contributes to increasing the rate of access to higher education, which is estimated at less than 5\% in Madagascar compared to about $8 \%$ to $20 \%$ in sub-Saharan Africa (according to UNIESCO). However, there are many advantages of ODL, among others: (1) A considerable reduction in State expenditure as students do not benefit from scholarships or university accommodation since most of the students' working time is spent at home; (2) An increase in the number of managers leaving the university in several sectors that contribute to the country's development; (3) Savings in students' time and travel expenses; (4) Improvement in the quality of higher education through the promotion of the digital university.

The main objective of the organization studied is to provide learners with training that is both academic and professional. On the one hand, it aims at the operationality of the students, eventually allowing them to integrate the professional world; and on the other hand, the pursuit of research training in Management Sciences to specialize in business management and administration, marketing and international trade, finance and accounting, auditing and management control, allowing the integration of the learners in high-level managerial activities.

Faced with these different opportunities, the characteristics of the actors' cooperation were studied through the form of cooperation within the ODL organization. The shift from the concept of vertical cooperation (according to the classical school) to transversal cooperation (concept of the school of human relations) leads to the search for the mechanism of community - organic cooperation in the organization of training. It is a space of consensus, integration, protection, in which all the actors wished to enter in order to live fully with others and share a common culture and values, according to Fiol Michel, Jordan Hugues, Sullầ Emili (2004). The concept of the so-called communitarianorganic cooperation has been studied through the constitution of social identification and the need for solidarity of the actors in a platform. Moreno Jacob's sociometry method was considered in order to determine the cooperation through the functioning of the group as well as the relations of sympathy and antipathy between the actors. In addition, Lewin's approach to the T. group made it possible to analyze the system of cooperation in the absence of teaching, administrative and technical staff during the student's personal work (SPW).

However, it should be remembered that the functioning of the body is a concrete example highlighted by Fiol Michel, JORDAN Hugues, SULLẦ Emili, (2004) to explain the community - organic cooperation. The organs of a body are both differentiated by functions and highly interconnected and united in their purposes. By analogy, the body is the organization of the ODL. According to Livian (1998): An organization is a system whose dynamics are the result 
The System of Cooperation of Actors in Open and Distance Learning

of interactions between a functional structure, human and physical resources and management systems, formal and informal, and whose efficiency can be measured by its ability to meet objectives. It is therefore in the organization of ODL that there are several groups of students, teaching staff and administrative and technical personnel who work at a distance according to different objectives.

The data were derived from participatory observation according to the approach of Lapassade, G. (2002). This observation made it possible to collect internal data in order to know the real situation experienced in the organization. Thus, the participation of 66 persons, legally registered at level 1 in License (L1) at the ODL during the $2018 / 2019$ academic year, made it possible to know the mechanisms of cooperation at the ODL of the University of Antananarivo. It must be admitted that this sample is limited to about $11.5 \%$ of all students, more precisely, 66 out of 573 individuals. For this purpose, all students enrolled in L1 were divided into groups of 50 individuals according to alphabetical order. Indeed, 11 groups of 50 students and 1 group of 23 students were formed. The latter group was not taken into account in the present research because of the insufficiency of the previously defined number of students and especially in order to avoid misinterpretation of the results obtained. An observation guide was sent to the 6 individuals in each group, resulting in a sample size of 66. The observations were based on the cooperation mechanisms between the different actors of the ODL both upstream and downstream, and even at the intermediate level. However, the approach of researching the configuration of cooperation processes within the ODL was adopted according to the Doz Y approach. (1996) on the definition and transformation of actors while considering the systems of objectives of these stakeholders. In the case of ODL, the process-based models on cooperation between teaching, administrative and technical staff and students thus describe feedback loops endogenous to the process and comprise three phases in the cooperative process of definition (without objectives), transformation (individual objectives) and reconfiguration of cooperative relations (common objectives). This phenomenon of "cooperation" is reflected in particular in the system of alliances between actors.

\section{RESULTS AND DISCUSSIONS}

Following the observation within the organization of the Management ODL of the University of Antananarivo, particular attention was paid to the form of community - organic cooperation. During the first phase on definition, the experimentation made it possible to identify the first three main actors of the ODL. These are teaching staff (TS=33\%), students ( $\mathrm{S}=27 \%$ ) and administrative and technical staff (ATS $=21 \%$ ). Other entities such as partners, enterprises, educational institutions, financial institutions and insurance institutions account for 18\% of the responses provided during the study. If this first step was carried out without mentioning the objective, the second one, which concerns transformation, took into account the individual objectives of all the actors. In the absence of teaching staff and administrative and technical staff, and especially when carrying out the student's personal work (SPW), breakdowns into groups of students were observed such as group 1(S), group 2 (S) to group n (S). This is the result of adopting Lewin's approach to the T. group. The last phase on the configuration made it possible to determine, taking into account Moreno Jacob's approach, the system of cooperation between the actors through the ODL platform (see diagram below). 


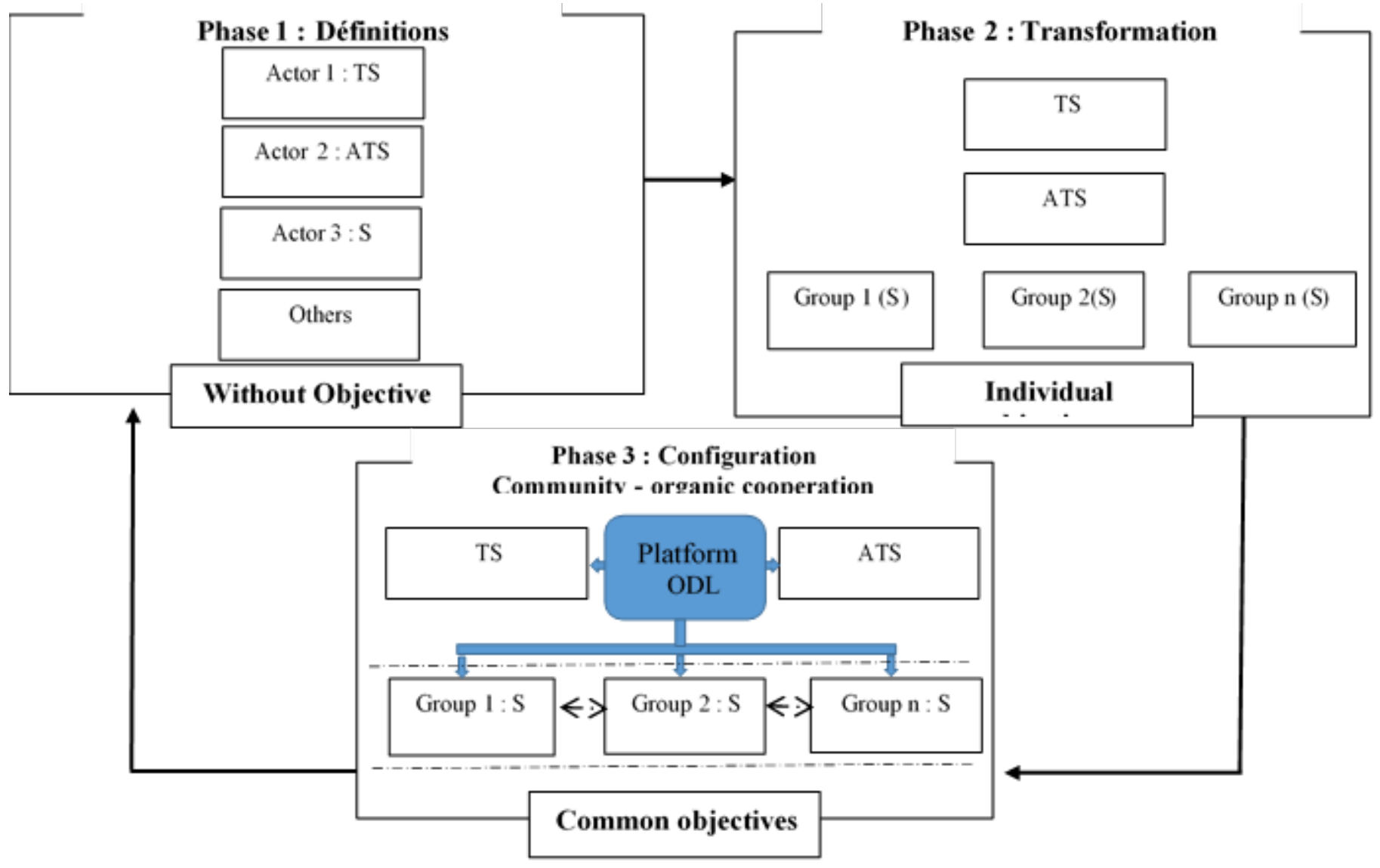

Figure 1: Cooperation process within the ODL

TS: Teaching Staff; ATS: Administrative and Technical Staff; S: Student

According to this scheme, the debate starts from the premise that no actor in the ODL works in a sustainable way in the direction of the general objectives of the ODL if he does not work at the same time in the service of his own objectives. If he fails to reconcile the interests of the ODL organization with his own, he will either betray the ODL organization by using it to achieve his personal goals at the expense of organizational goals, or he will sacrifice his own interests for a time and quickly feel betrayed. There may be conflicting visions on the theme of convergence of objectives or solidarity in the ODL organization. Another problem arises when these actors do not feel technically or pedagogically strong enough to be independent actors. As they need the protection of the ODL organization to develop individually, they prefer to join a collective work to better achieve their own objectives. They are willing to fully assume their responsibilities, make effective use of their entrepreneurial capacities to innovate and make every effort to achieve through their successes, in exchange for security in their career development. This vision can be described as a convergence of individual results and it is the basis for Community - organic cooperation. If each member of the ODL organization achieves the individual results to which it is committed, the organization as a whole considers this to be a satisfactory success.

Community - organic cooperation was observed in the groups on which students depend on the actions of other actors such as teaching, administrative and technical staff. The group membership model, on the other hand, assumes that the need to belong to the group is a very important aspect of social life (Maslow A., 1954). Actors want to be treated as prominent members of sustainable groups. They attach importance to procedural justice. Community organic cooperation is, in fact, seen as a tool for building group solidarity and ensuring strong bonds between its members. This is why, to enter a community, Fiol Michel, Jordan Hugues, Sullầ Emili (2004) assert that one must ask the actor for self-denial and humility, faith and obedience in order to divest oneself of individualism and accept to submit to the ethical rules of the community, to the values accepted by all.

To continue the debate, many researchers and authors in pedagogical sciences (Nicole Racette, Bruno Poellhuber and Marie-Pierre Bourdages-Sylvain, 2017) and especially in management sciences have long been talking about cooperation. The first reflection on cooperation, in the theories of organizations, was highlighted in the 
classical current. This school brings together thoughts from authors including Taylor F., among others. (1911) on the Scientific Labour Organization (or SLO), Fayol H. (1966) on the basic principles of management, Weber M. (1957) on authority relations within the company. The Scientific Labour Organization, as being at the center of managerial interest, generates a form of vertical cooperation. That is to say, cooperation should be exclusively vertical between superior and subordinates. In the ODL framework, the parties involved go beyond the two extremes of "superior subordinates". According to Arnaud Galisson (2004), there are several actors, namely the content expert (or teacher), the educational engineer, the technologist and the learner. While the first two are teacher-researchers, the other two are the administrative and technical staff and the students as a whole. Thus, three complementary entities are to be considered such as the teaching staff (TS), upstream, the students (S) downstream and the administrative and technical staff (ATS), at the intermediate level (see the diagram below).

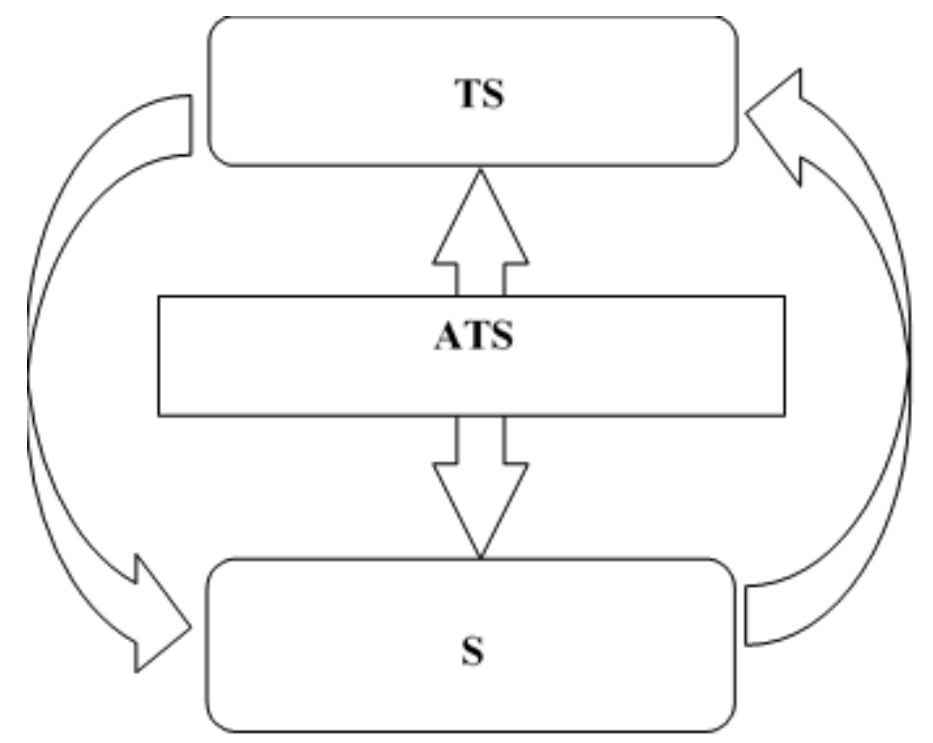

Figure 2: Vertical cooperation of ADF actors

PE: Teaching Staff; PAT: Administrative and Technical Staff; E: Student

Vertical coopération between these actors makes it possible to benefit from the complementarity of resources and skills, while reducing the risk of knowledge transfer (Hamouti, R., Robert, F. \& Le Roy, F., 2014). This complementarity is justified by the interdependence of individual interests. That is, an actor thus cooperates with other actors who have interdependent objectives. From this point of view, it is therefore essential to integrate oneself into the training process. The decision to cooperate therefore depends on the rational calculation of the individual. It is based on the economic reasoning of cooperative exchange, where everyone seeks to maximize their benefits. However, cooperation in the face of complementarity unfolds a framework with constraints related to the hierarchy between the actors (TS, ATS and S).

Taylor's idea of vertical cooperation has been criticized by many authors. Several authors such as Elton Mayo, Maslow Abraham (1954), MC Gregor (1960) have questioned this concept. First of all, a study conducted by Elton Mayo within Western Electric reveals the inaccuracy of strictly Taylorian conceptions (Astouric, Alain, 2004). Moreover, Darbelet M. et al. (1998) confirms that he can demonstrate the importance of the homogeneity of a working group (own objective, solidarity) and participation (discussion, cooperation in work efficiency). Moreover, Monie Roger (1986) notes that it seems that the foundations of the Taylorian organization precluded any systematization of the appreciation of individuals. Next, a theory on employee motivation was studied by Maslow (1954). This theory states that there is a scale of needs felt by people at work. The hierarchy of these needs concerns physiological needs, safety needs, group membership needs, self-esteem needs and self-actualization needs. Maslow's (1954) study shows that the man's motivation to cooperate is not limited to Taylor's wage system, but rather to these different needs, especially the need to belong to a group. Finally, the " $\mathrm{X}$ and $\mathrm{Y}$ " theories developed by MC Gregor (1960) in his book "The human side of enterprise", shows that, compared to theory X, theory Y therefore favours the "cooperation" of employees in the firm. 
A common point in their criticisms of cooperation concerns the failure to consider the human aspect during the Taylorian period. The paradigm of purely vertical cooperation, between superior and subordinates, conceived by Taylor may be paradoxical according to authors from the school of human relations. This school gives particular importance to human resources in cooperation. For example, Daniel Soulé and Dominique Roux (1992) consider the members of organizations to be key factors in the foundation of cooperation.

The emphasis on the human aspect leads to transversal cooperation whose foundations are not visible in the classical current. Human relations appear as a determining factor in the performance of an organization. The existence of forms of transversal relations, which follow an informal path, is recognized within the organization. According to Capul Jean-Yves (1998), these transversalités correspond to various forms of organization which, by their common characteristics, pose a specific management problem: how to organize the work of different competencies in the absence of a common hierarchical authority? This is the origin of transversal cooperation (cf. Diagram below).

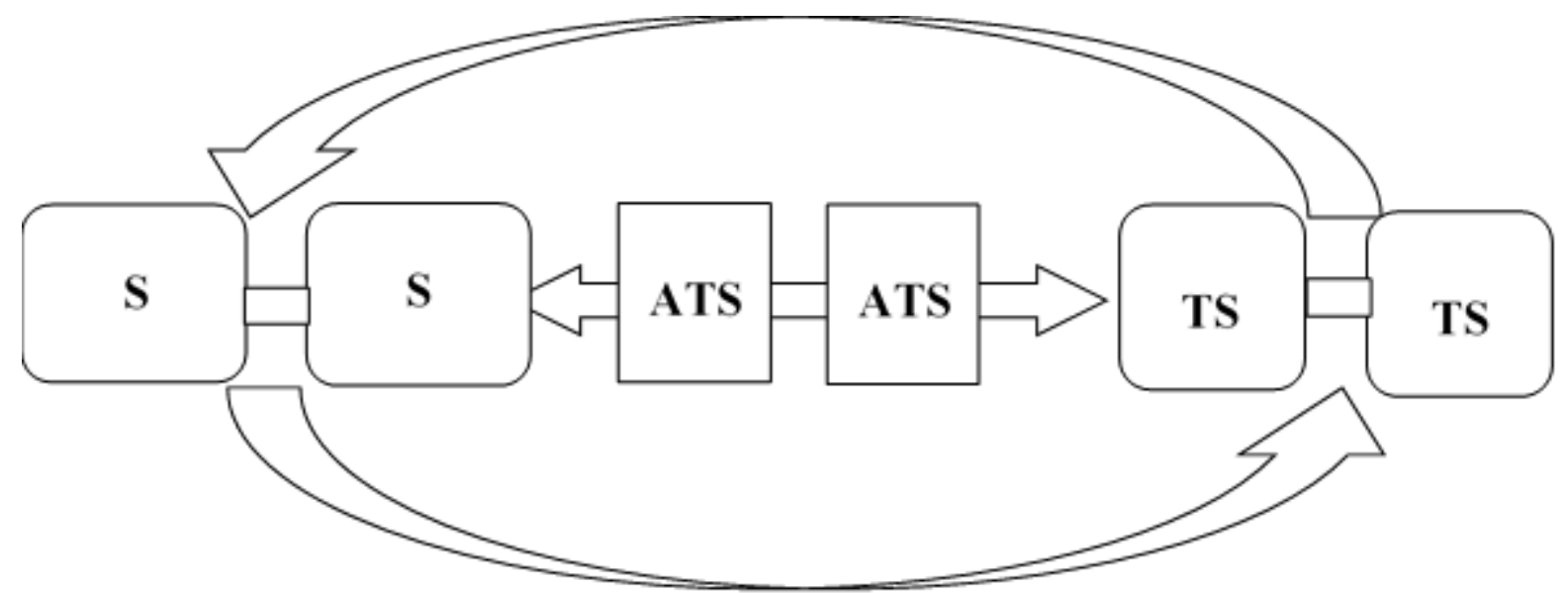

Figure 3: Cross-cutting cooperation between the actors of the ODL

TS: Teaching Staff; ATS: Administrative and Technical Staff; S: Student

The development of transversality between functions or, alternatively, between services immediately raises the question of cooperation. It is a question of getting a group of individuals working together who have no hierarchical link between them, who depend on different authorities and who often do not have the same hierarchical level.

Yet the development of cooperative practices is not innate. Within an organisation, cooperation takes on a special dimension. If in traditional economic theory, cooperation is opposed to competition, in the enterprise, it is rather opposed to the absence of relations and communications, to mutual ignorance and misunderstanding. The existence of cooperation as the main source of efficiency is thus reflected in the references increasingly marked by Japanese organizational models (Aoki M., 1991) in which the work collective dominates, making a contribution that exceeds the sum of individual contributions.

Consequently, the cross-cutting functions seek to bring together actors who are interdependent in the training process. Transversal cooperation is then justified, as it can improve the speed of information transmission and above all the flexibility of the ODL.

All in all, the Community - organic cooperation modality is seen as a combination of two forms of cooperation, i.e. vertical and transversal cooperation. It is within this framework that an attempt has been made to consider some approaches to cooperation and its evolution in the theories of organizations. These are cooperation in the classical current following the example of Taylor's approach and cooperation according to the school of human relations. From this perspective, the group is always considered as a place where cooperation is formed.

\section{CONCLUSION}

In conclusion, it must be admitted that there are other persons, both natural and legal, at national and even international level, who can be considered as actors in the field of ODL. However, this article deals with the system of cooperation only at the level of the three main actors in the ODL, namely the teaching staff, students and 
The System of Cooperation of Actors in Open and Distance Learning

administrative and technical staff. The observation was focused on the experimentation between these stakeholders of the ODL within the University of Antananarivo. Indeed, the result obtained was based on the system of communityorganic cooperation. From this perspective, social identification and solidarity, via the ODL platform, lead to the mutual recognition of actors such as students, teaching staff as well as administrative and technical staff. The use of the ODL platform, as a means of communication through forums, instant discussions and all forms of online interactions, promotes cooperation. The main reasons were justified by the spatial and temporal flexibility of ODL.

It has been found that cooperation means working collectively and jointly. Cooperation requires, at the level of the actors, actions of definition, transformation and configuration of reciprocal relations within the group. This leads to the knowledge of the essential point of cooperation in the world of distance learning. The social identification and collaboration of the students gathered in groups contribute to the realization of a common task. This interactive approach promotes creative autonomy, treats each student as an actor and develops individual and collective responsibility Drolet, I. \& Jacob, A. (1997). As a result, the actors cooperate with each other to develop and ensure the functioning of the ODL. This is why cooperation stems from all the social interactions in which the individual is involved (LIPIANSKI E-M., 1998). This community - organic cooperation using the ODL platform is thus a means of ensuring the functioning of an open and/or distance learning organisation.

\section{SOURCES OF FUNDING}

None.

\section{CONFLICT OF INTEREST}

None.

\section{ACKNOWLEDGMENT}

None.

\section{REFERENCES}

[1] Anne-lise UlmAnn. Les apprentis au cœur de «l'introuvable relation » formateur-tuteur. (L. D. française, Éd.) Revue française de sciences sociales, 2018, 11-26.

[2] Aoki M. Le management japonais : le modèle « J d'Aoki, Problèmes économiques, n²255, 1991.

[3] Arnaud Galisson. Concevoir et utiliser les formations ouvertes et à distance, Distances et savoirs. Vol. 2, nº. 1, 2004, 77 - 92

[4] Astouric Alain. Le management durable: du concret pour réussir ensemble, Lion chronique sociale; $2004,127$.

[5] Batime, C. \& Weber, E. La formation ouverte et/ou à distance, un levier pour des dispositifs de formation en mutation. Vie sociale, Vol.4, N.4, 2007, 127-150.

[6] Bourgeois, E. Nizet, J. Apprentissage et formation des adultes. Paris: Presses Universitaires de France. Collection «Education et formation».2005, (chap.8).

[7] Bowman, N. D. \& Akcaoglu, M. (2014). I see smart people! Using Facebook to supplement cognitive and affective learning in the university mass lecture. The Internet and Higher Education, 23, 2014, 1-8

[8] Capul Jean-Yves. Management et organisations des entreprises, Cahiers Français - La documentation française, Paris, 1998, 112.

[9] Cauvin Martine, Lacombe Jacques. De l'université ouverte à l'université virtuelle. Revue internationale d'éducation de Sèvres, 1999, 29-35.

[10] Cosnefroy Laurent, Lefeuve Sonia. Du travail de groupe à l'apprentissage collaboratif. Analyse de l'expérience d'étudiants en école de management », Revue française de pédagogie, Vol.202, 2018, 77-88.

[11] Darbelet M., Izard l., Scaramuzza M. Economie d'entreprise, Ed. Foucher, Paris, 1998.

[12] Denis, B. Quels rôles et quelle formation pour les tuteurs intervenant dans des dispositifs de formation à distance? Distances et savoirs, 1, 2003, 19-46. 
[13] Doz Y. The evolution of cooperation in strategic alliances: initial conditions or learning processes? Strategic Management Journal, vol. 17, 1966, 55-83.

[14] Drolet, I. \& Jacob, A. (1997). La coopération dans le monde et dans la classe. Revue des sciences de l'éducation, Vol. 23, N.1, 1997, 189-208.

[15] Elsbach, K. An expanded model of organizational identification, Research in Organizational Behavior, vol. 21, 1999, 163-200.

[16] Fayol H. Administration industrielle et générale, Dunod, Paris, 1966.

[17] Fiol Michel, Jordan Hugues, Sullầ Emili. Renforcer la cohérence d’une équipe : Diriger et déléguer à la fois, Dunod, Paris, 2004.

[18] Fluckiger Cédric. De l'émergence de nouvelles formes de distance. Les conséquences des nouvelles pratiques de communication ordinaires sur la FAD dans le supérieur. Distances et savoirs, Vol. 9, N.3, 2011, 397-417.

[19] Gérin-Lajoie S., Potvin C., Modèles de cours à distance dans une université bimodale, Présentation au congrès du Réseau canadien pour l'innovation en éducation (RCIÉ/CNIE), Banf, AB, Canada, 2008.

[20] Gérin-Lajoie Serge, Potvin Claude. Évolution de la formation à distance dans une université bimodale. Distances et savoirs, 2011, 349-374.

[21] Gregor MC. The human side of enterprise, McGraw Hill.1960.

[22] Grimbelle Hélène, Cois Antonin. L'éducation populaire au défi d'une société numérique. Cahiers de l'action, Vol.1, N. 48, 2017, 41- 45.

[23] Hamouti, R., Robert, F. \& Le Roy, F. (2014). Stratégie individuelle, stratégie de coopération verticale ou stratégie de coopétition. Quelle est la meilleure stratégie pour l'innovation produit? Innovations, Vol. 43, N.1, 2004, 135-161.

[24] Lapassade, G. Observation participante Dans: Jacqueline Barus-Michel éd., Vocabulaire de psychosociologie, 2002, 375-390.

[25] Lipianski E-M. Comment se forme l'identité des groupes, in J-C. Ruano-Borbolan (coord), L'identité, l'individu, le groupe, la société, Sciences Humaines édition, 1998, 143-150.

[26] Livian Y.-F. Organisation: Théories et pratiques, Dunod, Paris, 1998

[27] Maslow A. Motivation and personality, Harper et Row, New York, 1954.

[28] Monie Roger, De l'évaluation du personnel au bilan annuel, Ed. des Organisations, Paris. 1986.

[29] Nahla Aljerbi. Facebook : du FLE en Libye, Frantice.net, ${ }^{\circ} 10,2015$, 5-17.

[30] Ory Jean-Francis. Piloter le développement durable dans l'université : une expérience de construction d'un tableau de bord de la RSU. Gestion et management public, Vol. 7, N.2, 2018, 31- 54.

[31] Racette Nicole, Poellhuber Bruno. La coopération entre tuteurs et équipes de conception pour un meilleur suivi des cours à distance, Revue internationale de pédagogie de l'enseignement supérieur, Vol.33, N.2, 2017.

[32] Soulé Daniel, Roux Dominique. Gestion, Ed. PUF, Paris, 1992.

[33] Stines Marielle S. EDUCPOPNUM ou La constitution d'un collectif régional d'éducation populaire (au) numérique. (I. n. populaire, Éd.) Cahiers de l’action, 2017, 47-55.

[34] Taylor F. Les principes de la direction scientifique des entreprises, Éd. Dunod, Paris, 1911.

[35] Vadcard Lucile. Retour aux sources. Le modèle compagnonnique au service du tutorat. (L. D. française, Éd.) Revue française de sciences sociales, N.141, 2018,107- 116.

[36] Vincent Alonso Vilches et Florence Pirard. Le tutorat dans les métiers de l'interaction humaine. Revue française de sciences sociales, 2018, 27-44.

[37] Vladimir Iazykoff. Construire la compétence collective par la transmission entre générations: le tutorat, entre tradition et modernité". Revue française de sciences sociales, 2018, 89-105.

[38] Wallet Jacques. Entre pratiques réflexives et approches théoriques en formation à distance, questions croisées. Distances et savoirs, Vol.2, N.1, 2004, 9-23.

[39] Weber M. The theory of Social and Economic organisation, Free Press, New York.1957 